\title{
Engineering properties of ain (Terminalia elliptica) wood
}

\author{
S.P. DIVEKAR, S. K. JAIN, A. D. RANE, CHANDAN KUMAR, R. B. MAHADIK AND V. M. DAWARE
}

\begin{abstract}
Wood is one of the earth's most valuable resources and it conforms to the most varied requirement. There are over 1600 different species of woods which are used for various purposes. Wood shows a remarkably wide range of variation in their properties, timber and the type of end use (Rajput and Shukla, 1996). Wood is a multiuse biological raw material with a high economic importance for a number of industrial sectors such as construction, furniture and the packing industry. It is much more variable than that of materials such as concrete or metal (Michael, 2016). Global production of wood is estimated at 3469 million $\mathrm{m}^{3}$ in 2011, of which 1891 million $\mathrm{m}^{3}$ is fuel wood and 1578 million $\mathrm{m}^{3}$ is industrial round wood. Wood is a natural, renewable and valuable construction material. Since being thought of as naturally resistant to wood degrading organisms. Wood has been used as a shelter and has many outdoor applications thought out human history. However, the durability of wood varies depending on its tree species, chemical composition and the environmental condition. Wood biodegradation occurs in different ways such as fungal, bacterial and insect attack. Fungal decay is the most widespread type of wood degradation. The demand for wooden products is continuously increasing day by day. Wood is exposed to both periodic water absorption and desorption process. Understanding water absorption and desorption in wood are of practical importance since they also affect the mechanical properties of the product. In residential building and in industrial application some of the components are often wood (Ostman, 1985). To develop buildings and its components different engineering properties are important. In the present study, the bending stress of ain was found as $5.67 \times 10^{7} \mathrm{kN} / \mathrm{m}^{2}$ and compression stress was found as $1.3 \times 10^{7} \mathrm{kN} / \mathrm{m}^{2}$.
\end{abstract}

KEY WORDS : Ain, Moisture content, Shrinkage, Bending stress, Compression stress

How to cite this Article : Divekar, S.P., Jain, S.K., Rane, A. D., Kumar, Chandan, Mahadik, R.B. and Daware, V. M. (2017). Engineering properties of ain (Terminalia elliptica) wood. Engg. \& Tech. in India, 8 (1\&2) : 23-28; DOI : 10.15740/HAS/ETI/8.1\&2/ 23-28. 